\title{
Ethical Rigorism of Kant and Theological Moralism of Crusius
}

\author{
Ludmila Kryshtop \\ History of Philosophy Department \\ Peoples' Friendship University of Russia \\ 6 Miklukho-Maklaya Str. \\ Moscow, Russia \\ E-Mail: kryshtop_le@rudn.university
}

\begin{abstract}
Kant is a well-known philosopher famous for his categorical imperative, which requires a human being to display purely moral determination to act. That is why his ethics is also often characterized as strictly rigorous. At the same time, Kant himself seems to try to eliminate all foreign components from the determination of will, including hope for God's remuneration or fear of God's punishment. Also, there exists a thinker who comes very close to Kant's views Christian Crusius. Trying to explicitly distinguish his own position the views of Crusius, in his Critique of Practical Reason Kant claims Crusius to be a theological moralist and criticizes this way of foundation of basic moral principles. The article concerns both similarities and differences between the positions of these two great thinkers of German Enlightenment and attempts to answer the question whether the differences can be regarded as significant.
\end{abstract}

Keywords-Kant; Crusius; morality; ethics; moral law; God; postulate; religion

\section{INTRODUCTION}

The ethic conception of Kant is often characterized as rigorism. This is caused by his emphasizing the duty, expressed in form of categorical imperative, and unconditional following it as the principal requirement of morality. Yet, such a characterization of Kant's ethics causes difficulties, as assuming Kant's ethics to be rigorous and formalistic we can ask a justified question whether the Kant's postulates of practical reason do not break the purity of his moral theory. First of all, it touches on the postulates of God's existence and immortality of soul. For Kant these principles were regarded as important and necessary part of his ethics, for us they seem to be superfluous, needless and just foreign components of Kant's moral theory. How can it be possible to connect the purity of Kant's will determination and postulates of practical reason, especially postulates of God's existence and immortality of soul? And whether these two practical principles were really necessary for Kant to build an ethical system or were they only superfluous components caused by the previous spiritual and intellectual tradition?

\section{ETHICAL RigORISM OF KANT AND His POSTULATES DOCTRINE}

In order to find an answer to such questions it is worth to analyze more precisely the contradictions we deal with when we try to connect the postulates doctrine expressed evidently in the second Critique with the foundations of Kant's ethics as they are formed in the Foundations of the Metaphysics of Morality. On the one hand, Kant stresses that we can speak of morality only in case when the human will be free. It can be free only if it is determined by the principles of universal legislation. As bringing any kind of concrete matter such as end goals of the action into the will's determination process would bring empirical components with it, the free will can be determined only as a mere form of universal legislation. And so, we come to the Kant's famous categorical imperative commanding us to act in the way "that the maxim of your will could always hold at the same time as a principle of a universal legislation" [1]. This formulation from the Second Critique follows in its main features the principal result of the Foundations of the Metaphysics of Morality. Besides, it must be noticed that closer to the end of the second Critique we find also an extended presentation of postulates doctrine [2] based on doctrine of the highest good we have already met in the text before. It turns out that according to Kant the highest good is the only possible end goal the pursuit of which not only keeps the purity of the moral law unbroken but also should be built into the categorical imperative itself.

Another, even more difficult, problem arises if we try to analyze what components the highest good consists of. It turns out that one of these components is happiness, though Kant repeatedly stressed that happiness as the object of our will can only underlie the principles of selfishness, that is hypothetical imperative, and thus cannot comply with the requirements of the moral law. Kant explained that happiness is not and cannot be in this case the goal itself but only the result of fulfillment of the first components of the highest good which is virtue. And here we have a paradox. The achievement of happiness is possible only if we are virtuous and virtue can be reached only on the condition of fulfilling the commandments of the moral law which excludes happiness from the possible moral motives. On the basis of 
connection of these two components which are necessary for us men to have a hope of fulfillment of moral law and so of achieving happiness Kant constructs his postulates doctrine. He postulates existence of God who must bring in accordance our happiness with our virtue. Of course, Kant makes here also many reservations. The postulate of God's existence is not necessary for us to be virtuous. Even if we do not have a hope to achieve happiness as a result of our virtue we can and must nevertheless follow the moral law. In order to demonstrate it more clearly Kant gives us an example of the atheist Spinoza in the third Critique, who has no faith in God but is in spite of that a virtuous man. But even in this example Kant holds faith in God not necessary for being virtuous but necessary for realizing the commandment of the moral law in fullness: "Therefore, let us consider the case of a righteous man (Spinoza, for example) who actively reveres the moral law [but] who remains firmly persuaded that there is no God and (since, as far as [achieving] the object of morality is concerned, the consequence is the same) that there is also no future life: How will he judge his own inner destination to a purpose, [imposed] by the moral law? He does not require that complying with that law should bring him an advantage, either in this world or in another; rather, he is unselfish and wants only to bring about the good to which that sacred law directs all his forces. Yet his effort [encounters] limits: For while he can expect that nature will now and then cooperate contingently with the purpose of his that he feels so obligated and impelled to achieve, he can never expect nature to harmonize with it in a way governed by laws and permanent rules (such as his inner maxims are and must be). ... And so, this well-meaning person would indeed have to give up as impossible the purpose that the moral laws obligated him to have before his eyes, and that in compliance with them he did have before his eyes“" [3].

This argumentation seems to be inconsequent and contradicting for us today. But we have at the same time to admit that Kant saw there no contradictions at all. How can it be understood and explained? One possible way is to assume that we deal with hidden eudemonism, which was characteristic for Kant in the early period and could be not completely eliminated [4] [5]. Another explanation is to suppose that we see something like a tribute to the Christian tradition Kant was grown up in, which resulted in introducing into Kant's ethics the components which are alien and unnecessary for it but which for Kant himself did not seem to be such. This situation is complicated due to the fact that Kant tried to depart from the theological moral and for this reason we find in the second Critique a passage intended against the basic principles of ethics of Crusius whom Kant ranked among "theological moralists" [6]. But if we read the writings of Crusius we get an impression of reading Kant himself for the amount of similarities they have. And these similar features we find in the basic views of these two thinkers. So, in order to understand Kant's ethics better it could be worth putting under scrutiny the ethical views of Crusius which have so many common features with Kant's ones but which Kant himself nevertheless criticized openly.

\section{THE MORAL DOCTRINE OF CRUSIUS}

Christian August Crusius (1715-1775) was a well-known theologian who became famous at first thanks to his irreconcilable critique of the philosophy of Christian Wolff. The main object of his criticism was the principle of sufficient reason dating back to Leibniz's philosophy whose follower Wolff was considered to be. According to Crusius it can make a great damage to religion and morality if it were widely spread [7]. The important aspects of philosophical views of Crusius were the problem of the freedom of human will and its theoretical argumentation. In the way in which Crusius tried to argument the thesis about the freedom of will the researchers have since the beginning of the 20th century been noticing a great similarity to Kant [8]. But even more similar features we can see in the way Crusius touches upon the essence of practical principles. He divides all practical principles into laws of virtue and rules of prudence. They differ from each other because of their objects and the nature of their obligatory force. In the case of rules of prudence, we deal with objects arbitrarily determined by the acting subject himself and so being occasional ones. For this reason, their obligatory force cannot be unconditionally necessary. We need such rules only as means for achieving our goals if we chose them. On the contrary, the laws of virtue have absolutely necessary object and so have an unconditional obligatory force [9]. Such an object according to Crusius can only be achieving the highest good by connecting virtue and happiness, yet only in such way that happiness cannot be the end goal, it can only be a consequence of our virtue. Still Crusius himself understood well the paradox we deal with in this case, namely, that a human being can receive happiness only as a consequence of his virtue, but in order to be virtuous he must not seek happiness as a goal of his action. Therefore, Crusius defined virtue as the correspondence of our action to moral law [10]. So, the moral philosophy of Crusius seems to be nearly identical with Kant's views. But if it is really so, where are the roots of Kant's critique of Crusius?

\section{KANT AND CRUSIUS: DIFFERENCES AND SIMILARITIES}

To answer this question, it is time to turn to analyzing with more precision the essence of moral law and its commandments by Crusius. Being virtuous is the principal requirement of moral law, and Crusius gives only one (but in his opinion sufficient) argument in favor of that. It is so because of God's will, according which a human being as the greatest creation of God must increase the perfection of the world in all possible ways. So, the highest good with virtue as an absolutely necessary component is the final goal for human being because God wanted in the creation of the world the human being to be virtuous [11]. And for a human being the will of God is an immutable law. We see that the moral law in the philosophy of Crusius is derivative of the will of God. Thus, this is the first circumstance which is seen as the principal difference from the ethics of Kant.

The second difference is the essence of moral motives by Kant and Crusius. Both thinkers stress that pure virtue must be the goal according to the commandments of moral law. Both also emphasize that we need to consider not only the 
external side of actions but also internal motives the person while undertaking them. At the same time the mere moral motives can be only a formal principle as the introduction of any material components in process of deciding would break the pureness of will's determining. While for Kant this moral principle that could be only a formal one is the respect for moral law, for Crusius it is obedience to the will of God. And here also we see the theological aspect of the moral thought of Crusius what is regarded as the main difference between the two thinkers of age of German Enlightenment.

Still, this obvious difference between Kant and Crusius exists nevertheless only until we turn to Kant's postulates doctrine which is based on Kant's notion of the highest good. The introduction of postulates of practical reason into the moral conception of Kant breaks this well-proportioned picture in its essentials. Especially if we consider Kant's notice that the transition from moral to religion is natural and unavoidable for men: "In this way the moral law, through the concept of the highest good as the object and the final purpose of pure practical reason, leads to religion, i.e., to the cognition of all duties as divine commands, not as sanctions - i.e., chosen and by themselves contingent ordinances of another's will - but as essential laws of every free will by itself. [Even as such,] these laws must nonetheless be regarded as commands of the supreme being, because we can hope to reach the highest good, which the moral law makes it our duty to posit as the object of our endeavor, only through a will that is morally perfect (holy and benign) and simultaneously also all-powerful, and thus through harmony with this will" [12]. If Kant himself states that we must naturally consider the requirements of the moral law as commandments of the holy God, where can we see a further difference between Kant and Crusius?

In this connection we can also mention a fragment of another writing of Kant, The Metaphysics of Morals, where the essence of conscience is discussed. Here we read: "But man as the subject of the moral lawgiving which proceeds from the concept of freedom and in which he is subject to a law that he gives himself (homo noumenon) is to be regarded as another (specie diversus) from man as a sensible being endowed with reason, though only in a practical respect for there is no theory about the causal relation of the intelligible to the sensible - and this specific difference is that of the faculties (higher and lower) of man that characterize him" [13]. A person being a part of intelligible world passes a judgment on himself, but in the following it turns out such derivation into two subjects is not sufficient and that the action has been judged with full strictness according to the requirement of moral law. And so, the practical reason has to create an idea of God having all moral attributes and all of them in the highest degree so that the right judgement on men could be pronounced.

This text fragment has a great importance for us because here Kant comes close to identifying God as the practical reason. This fact destroys the advantage of those researchers who attempt to argue that the main difference between Kant and Crusius is in their way to consider the nature of the legislator of moral law. When in the philosophy of theological moralist Crusius it is God, for Kant it is the practical reason itself. If we suppose the practical reason and God to be one and the same this difference disappears. At the same time, I am not inclined to assume no principle difference between the two thinkers. I state only that this difference lies in a different sphere. It is to be found not in the contents of principles but in the way, they are introduced into the philosophical system. Considering solely the content of moral principles by Kant and Crusius we must state that their views are nearly identical. The most important is the virtue. It consists in non-selfish fulfillment of the requirements of moral law. To be virtuous is the final goal of a human being because of commandment of God or of the practical reason necessarily regarded by human being as God. The principle difference is that Crusius holds these foundations as truths in themselves while for Kant they are only the objects of our faith.

\section{CONCLUSION}

We have analyzed the moral philosophy of two thinkers of German Enlightenment. One of them is Kant who is wellknown all over the world thanks to his categorical imperative and rigorous ethics of pure moral determination of will. The other one is Crusius, a theologian and philosopher well known in his time. We have shown many similarities that exist in the views of these thinkers. These similarities are so significant that we have right to suppose a possibility of a direct influence of Crusius' philosophy on Kant. If we look only at the content of moral principles of Kant and Crusius we are to state that they come closely to each other. In spite of this proximity there is also a principal difference which consists in the way God's existence is introduced into moral systems. For Crusius the fact that God exists is a truth in itself; for Kant it is an object we need to believe in without knowing whether it is really so. Kant does not state that it is really so. He only says we have to believe that it is so, as this way of thinking is optimal for achieving the end goal which is the highest good. It is in this way of supposing these practical principles and not in their contents as such where is the essence of Kant's famous postulates of practical reason.

\section{REFERENCES}

[1] I. Kant, Critique of Practical Reason, Cambridge: Indianapolis 2002 p. 30 .

[2] Ibid., p. 155-184

[3] I. Kant, "Critique of Judgment", Cambridge: Indianapolis 1987, p. 341-342.

[4] H. Schmitz, Was wollte Kant, Bonn 1989, pp. 81-100.

[5] M. Kühn, "Einleitung", in Immanuel Kant. Vorlesung zur Moralphilosophie, hrsg. von W. Stark, Berlin / New York 2004, S. XXXIII Anm.

[6] I. Kant, Critique of Practical Reason, p. 40.

[7] Ch. A. Crusius, Ausführliche Abhandlung von dem rechten Gebrauche und der Einschränkung des sogenannten Satzes vom zureichenden oder besser Determinirenden Grunde, Leipzig 1744, pp. 28-32, 20-21

[8] H. Heimsoeth, Metaphysik und Kritik bei Chr. A. Crusius. Ein Beitrag zur ontologischen Vorgeschichte der Kritik der reinen Vernunft im 18. Jahrhundert, Berlin 1926, pp.. 44, 51-52.

[9] Ch. A. Crusius, Anweisung vernünftig zu leben, Leipzig 1767, b3. 
[10] Ch. A. Crusius, Kurzer Begriff der Moraltheologie, oder Erklärung der praktischen Lehre des Christentums, Tl. 1, Leipzig 1772, p. 44.

[11] Ch. A. Crusius, Anweisung vernünftig zu leben, Leipzig 1767, pp. 33, $184-185,190$

[12] I. Kant, Critique of Practical Reason, pp. 163-164.

[13] I. Kant, The Metaphysics of Morals, Cambridge: Cambridge University Press, 1991, p. 234. 